\title{
BIOENERGETICS OF CAMEL CRICKETS (CEUTHOPHILUS CARLSBADENSIS, C. LONGIPES AND C. CONICAUDUS) FROM CARLSBAD CAVERNS NATIONAL PARK, NEW MEXICO
}

\author{
Diana E. Northup, Kathleen H. Lavoie* and Eugene H. Studier* \\ Museum of Southwestern Biology, Department of Biology, University of New Mexico, Albuquerque, \\ NM 87131-1091, U.S.A. (Tel. 505-277-5232); *Department of Biology, University of Michigan-Flint, \\ Flint, MI 48502-2186, U.S.A. (Tel. 313-762-3360)
}

(Received 14 December 1992; accepted 29 January 1993)

\begin{abstract}
Ahstract-1. Camel crickets in Carlsbad Caverns National Park exhibit linear long-term weight loss patterns for combined sexes of $1.05 \mathrm{mg} / \mathrm{hr}$ for Ceuthophilus carlsbadensis, $0.261 \mathrm{mg} / \mathrm{hr}$ for C. conicaudus, and $0.321 \mathrm{mg} / \mathrm{hr}$ for $C$. longipes.

2. From these patterns, maximal foraging intervals for females and males, respectively, of 5.1 and 4.4 days for $C$. carlsbadensis, 4.6 and 5.7 days for $C$. longipes, and 5.0 and 4.2 days for $C$. conicaudus were predicted.

3. Calculated metabolic rates (cal/hr) of 1.04 for $C$. carlsbadensis and 0.52 for $C$. longipes were half that predicted for epigean species of similar size.
\end{abstract}

\section{INTRODUCTION}

Or:hopterans show different levels of adaptation to life in caves. Guano, eggs and carcasses of these carernicolous crickets may be important energy resources in caves, especially in areas which lack extensive guano inputs from birds or bats (Studier et al., 1986). Carlsbad Cavern in Carlsbad Caverns National Park, Eddy County, New Mexico, is home to extensive cave swallow (Hirundo fulva) and Mexican free-tailed bat (Tadarida brasiliensis) populations which roost in defined areas in or near the entrance, respectively. Most of the extensive Cavern (approxime tely $33.8 \mathrm{~km}$ of passage) and smaller caves in the Park, including Spider Cave, have limited food resources due to the aridity of the surrounding region and lack of seasonal flooding.

Three species of "cave cricket" or "camel cricket" rhitphidophorids inhabit these caves. Spider Cave is pridominantly populated by Ceuthophilus conicaudus while $C$. carlsbadensis and $C$. longipes occur in Carlsbad Cavern. C. carlsbadensis occurs primarily on extensive guano deposits under the bat roosts and in areas visited by humans while $C$. longipes predominctes in areas of the cave that are more food-limited. The biology of these three species is described by Bailey (1928), Campbell (1974, 1976) and Northup (1488), and the taxonomy by Caudell $(1916,1924)$ and Hubbell (1936). Based on morphological characteristics, extremes of cave adaptation are seen with the little adapted $C$. carlsbadensis, living in food-rich areas, and the smaller, more cave-adapted $C$. longipes found in food-poor areas. C. conicaudis is also found in food-poor areas, but shows fewer morphological adaptations than $C$. longipes. We present compara- tive data on the energy budgets and water budgets of these three cavernicolous cricket species to provide information on their energy contribution to a cave ecosysytem situated in an arid environment, and compare them to cavernicolous crickets from central Kentucky.

\section{METHODS AND MATERIALS}

Adult $C$. carlsbadensis (eight males, eight females) were hand-collected from Bat Cave in Carlsbad Cavern. Adult and juvenile $C$. longipes (eight males, six females) were collected in unbaited pit-fall traps from Sand Passage in Carlsbad Cavern. Adult C. conicaudus (seven males, eight females) were handcollected from the entrance crawlway of Spider Cave.

A long-term weight loss study was set-up in Left Hand Tunnel, Carlsbad Cavern, from 14-18 May 1989 for $C$. carlsbadensis and C. conicaudus, and from 15 and 16-19 May 1989 for $C$. longipes. At the start of the study, crickets were weighed to the nearest $0.1 \mathrm{mg}$ with an electronic balance (Fisher Scientific, Model 2100). Crickets were caged individually without food or water in pint canning jars. Each jar had a strip of plastic screencloth on the inside to provide a rough surface for climbing and roosting. Jars were sealed with plastic screencloth held in place by canning rings. The ambient temperature at the study site was the typical constant deep cave temperature of $15.2^{\circ} \mathrm{C}$ with a minimum relative humidity (r.h.) of $90.2 \%$.

Crickets were weighed twice daily for the first 2 days and once daily for the remaining time. As the study of each group of crickets was terminated, 

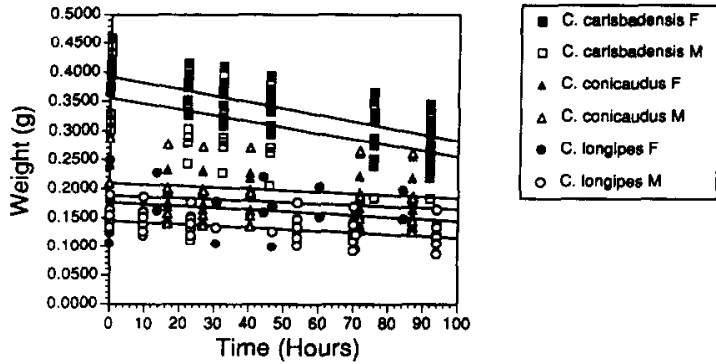
a C. carlsbadensis $M$

- C. conicaudus $F$

$\triangle$ C. conicaudus $M$

- C. longlpes $F$

C. longipes $\mathrm{M}$

Fig. 1. Weight loss with time for female (F) and male (M) $C$. carlsbadensis, $C$. conicaudus and $C$. longipes. The regression for each is plotted.

crickets were frozen and dissected to separate carcasses, reproductive parts and crops and wet and dry weights were determined. Hind femur lengths (HFL) were measured to the nearest $0.1 \mathrm{~mm}$ using calipers. Guano produced during the study was collected, dried and weighed. Caloric density of samples were determined using a Parr oxygen bomb calorimeter. Carcasses were bombed individually while other samples were pooled to obtain a large enough sample. See Studier et al. (1986, 1987a,b) for details of the methodology.

\section{RESULTS}

Weight loss with time shows a linear decrease for all three cricket species with $C$. carlsbadensis losing weight most rapidly (Fig. 1). Regression equations are also plotted in Fig. 1, while significant and nearly significant regression equations are given in Table 1 . Live weight loss with time for both female and male C. carlsbadensis is highly significant. Neither female nor male $C$. conicaudus weight loss with time was significant, however, combined male and female weight loss with time is nearly significant. Female C. longipes demonstrated a non-significant relationship of weight loss with time while males had a highly significant weight loss with time.

Energetic parameters for the three study species are presented in Table 2. [For calculations used to generate the data in Table 2, see Studier et al. (1986, 1987a,b)]. As evidenced by lowest carcass caloric density, $C$. carlsbadensis, from the most predictable food environment, has the least body fat reserves while $C$. longipes from the least predictable food environment has the largest amount of body fat (Table 3). Female crickets may show lower carcass caloric density than males because of removal of lipid-rich ova from the carcass during analysis. Female $C$. longipes in this study were mostly subadults without mature ova, resulting in higher carcass caloric density. Data are incomplete for $C$. conicaudus and $C$. longipes because of small sample size. It is interesting to note that the food available to C. carlsbadensis in Bat Cave (bat guano) has nearly identical caloric value to its crop contents.

Water budget component levels are shown in Table 4 for $C$. carlsbadensis and $C$. longipes and compared with two cavernicolous crickets from Mammoth Cave, Ceuthophilus stygius and Hadenoecus subterraneus.

Metabolic rates (MR) are compared (Table 5) as weight-specific MR, cxpected MR and actual MR for $C$. carlsbadensis and $C$. longipes, and compared with the two Mammoth Cave cricket species.

\section{DISCUSSION}

Weight loss in the three Carlsbad species of Ceuthophilus studied was linear (Fig. 1). Studies of cavernicolous rhaphidophorids from Kentucky showed a curvilinear weight loss for C. stygius (Studier et al., 1987a) and a linear weight loss for the more cave-adapted Hadenoecus subterraneus (Studier et al., 1986). The Carlsbad cricket with the least cave-adapted phenotype, $C$. carlsbadensis, showed the most rapid weight loss. An unexpected result is the similarity in rate of weight loss for the other two crickets. $C$. conicaudus shows some cave phenotypes in its pale coloration but has robust, relatively short femora in comparison to the more cave-adapted C. longipes (Studier and Lavoie, 1993). While $C$. conicaudus is mostly found in the twilight and entrance areas of caves, $C$. longipes is usually encountered deep in caves. Further investigation of the physiology and ecology of $C$. conicaudus is needed.

Weight loss over the short period of time of the study represents emptying of the crop and thus is useful in predicting when crickets should leave the cave to forage to avoid utilizing fat reserves (Studier et al., 1986). The linear weight loss data can be extrapolated to intercept the crop empty live weight of each species to predict maximum foraging intervals. Predicted foraging intervals for females and

Table 1. Regression coefficients for weight loss with time

\begin{tabular}{|c|c|c|c|c|c|c|c|c|}
\hline & $\mathbf{a}$ & SE & b & SE & $F$ & d.f. & $P$ & $r^{2}$ \\
\hline \multicolumn{9}{|l|}{ C. carlsbadensis } \\
\hline Females & -1.07 & \pm 0.16 & 375 & \pm 51 & 47.1 & 46 & $<0.0001$ & 0.506 \\
\hline Males & -1.02 & \pm 0.26 & 355 & \pm 57 & 14.9 & 46 & 0.00004 & 0.245 \\
\hline \multicolumn{9}{|l|}{ C. conicaudus } \\
\hline Combined sexes & -2.61 & \pm 0.14 & 199 & \pm 43 & 3.31 & 94 & 0.072 & 0.034 \\
\hline \multicolumn{9}{|l|}{ C. longipes } \\
\hline Females & - & - & - & - & 2.034 & 26 & 0.166 & 0.072 \\
\hline Males & -0.321 & \pm 0.098 & 145 & \pm 22 & 9.05 & 44 & 0.0043 & 0.171 \\
\hline
\end{tabular}

Weight in $\mathrm{mg}=\mathrm{a}$ (time in $\mathrm{hr}$ ) $+\mathrm{b}$. SE is the standard error. 
Table 2. Energetic parameters for camel crickets, Ceuthophilus carlsbadensis, $C$. conicaudus and C. longipes

\begin{tabular}{|c|c|c|c|c|c|c|c|c|c|c|}
\hline \multirow[b]{2}{*}{ Variable } & \multirow[b]{2}{*}{ Units } & \multicolumn{3}{|c|}{$\begin{array}{c}\text { C. carlsbadensis } \\
92 \mathrm{hr}\end{array}$} & \multicolumn{3}{|c|}{$\begin{array}{l}\text { C. conicaudus } \\
87 \mathrm{hr}\end{array}$} & \multicolumn{3}{|c|}{$\begin{array}{c}\text { C. longipes } \\
71-94 \mathrm{hr}\end{array}$} \\
\hline & & $x$ & $\pm \mathrm{SE}$ & $N$ & $x$ & $\pm \mathrm{SE}$ & $N$ & $x$ & $\pm \mathrm{SE}$ & $N$ \\
\hline HFL & $\mathrm{mm}$ & 11.47 & 0.12 & 16 & 10.24 & 0.23 & 16 & 12.59 & 0.16 & 14 \\
\hline CELW & $\mathrm{g}$ & 0.2836 & 0.0092 & 16 & 0.1660 & 0.0093 & 16 & 0.1202 & 0.0050 & 14 \\
\hline $\begin{array}{l}\text { dry }(t=0) \\
\text { fraction }\end{array}$ & $\%$ & 29.21 & 0.37 & 11 & 28.20 & 0.59 & 2 & 29.26 & 0.51 & 7 \\
\hline $\begin{array}{l}\text { dry }(t=\text { end }) \\
\text { fraction }\end{array}$ & $\%$ & 32.51 & 0.83 & 16 & 28.97 & 0.50 & 15 & 33.96 & 2.41 & 14 \\
\hline $\begin{array}{l}\text { crop wt. } \\
\text { loss }\end{array}$ & $\mathrm{mg} / \mathrm{hr}$ & 1.071 & 0.163 & 96 & 0.261 & 0.143 & 96 & 0.321 & 0.115 & 74 \\
\hline avg. dry crop & $\mathrm{mg} / \mathrm{hr}$ & 0.3305 & & 16 & 0.0746 & & 16 & 0.1015 & & 14 \\
\hline $\begin{array}{l}\text { dry wastes } \\
\text { produced }\end{array}$ & $\mu \mathrm{g} / \mathrm{hr}$ & 66.80 & 7.0 & 16 & 15.17 & 2.34 & 16 & 7.76 & 1.37 & 14 \\
\hline $\begin{array}{l}\text { dry assimil. } \\
\text { efficiency }\end{array}$ & $\%$ & 79.79 & & 16 & 79.66 & & 16 & 92.35 & & 14 \\
\hline cal (in) & $\mathrm{cal} / \mathrm{hr}$ & 1.314 & & 16 & & & & $0.5511^{*}$ & & 14 \\
\hline cal (out) & $\mathrm{cal} / \mathrm{hr}$ & 0.2700 & & 16 & & & & $0.0314 \uparrow$ & & 14 \\
\hline caloric AE & $\%$ & 79.46 & & 16 & & & & 94.30 & & 14 \\
\hline MR & $\mathrm{cal} / \mathrm{hr}$ & 1.044 & & 16 & & & & 0.520 & & 14 \\
\hline $\begin{array}{l}\text { wt specific } \\
\text { MR }\end{array}$ & $\mathrm{cal} / \mathrm{g} / \mathrm{hr}$ & 3.681 & & 16 & & & & 4.324 & & 14 \\
\hline
\end{tabular}

*at $5.430 \mathrm{Kcal} / \mathrm{g}$ dry; tat $4.042 \mathrm{Kcal} / \mathrm{g}$ dry.

Values shown are mean and standard error of the mean. HFL $=$ Hind Femur Length. CELW $=$ crop-empty live weight $\mathrm{MR}=$ metabolic rate.

me les, respectively, of each species are; $C$. carlsbadensis 5.1 and 4.4 days, $C$. conicaudus, 5.0 and 4.2 days; and $C$. longipes, 4.6 and 5.7 days. These predictions ar: intermediate to those reported by Studier et al., (1196, 1987a) for C. stygius (3.0 and 2.3 days) and $H$ subterraneus (11.5 and 9.9 days), although closer to $C$. stygius foraging intervals.

We note essentially no differences in foraging intervals for any of the Carlsbad Ceuthophilus, regardless of degree of cave adaptation or the food availability in each environment. C. carlsbadensis, the least caveacapted species living in a food rich environment w. ould not need to forage frequently, but we expected to find longer foraging intervals in the more cave ariapted species.

Most of the C. longipes studied by Northup (1988) and those in this study had nearly empty crops, e) cept those collected by Northup in Bat Cave, the fcod-rich bat roost area. Based on trapping data (Northup, unpublished data) these crickets seldom leave the cave to forage, and probably adopt a cunstant foraging strategy in the deep cave regions of $\mathrm{kw}$ food availability. Foraging also influences body $f: t$ reserves, and $C$. longipes may maintain greater fat siores than the other two species (Table 3) to carry them through periods of starvation or low food input.
A study of $C$. conicaudus in Spider Cave, Carlsbad Caverns National Park (Campbell, 1976), showed that many $C$, conicaudus leave the cave to forage every third night. These crickets do not forage nightly, but do leave to forage before their crops would be completely empty.

Crickets in Carlsbad Caverns National Park may forage more frequently than expected because of poorer foraging opportunities in the arid environment surrounding the caves. The crickets studied by Studier and Lavoie (1990) forage only when epigean humidity is high, which is less likely with the Ceuthophilus crickets in this study, as desert air is rarely saturated, although NPS weather station data from Carlsbad does show that nights of high maximum r.h. $(>90 \%)$ do occur throughout the year. Alternatively, there may be physical restrictions on how much a crop can expand to accommodate forage. Further studies are required.

Studier et al. $(1986,1987)$ noted that male crickets in Mammoth Cave National Park foraged more frequently than females, since they were unable to consume as much food in a single feeding bout. The need to leave the refuge of the cave to forage more frequently, put males at greater risk of epigean predation and probably accounted for the typically

Table 3. Caloric contents of carcasses, crop contents, ova and food of Ceuthophitus carlsbadensis, $C$. conicaudus and $C$. longipes

\begin{tabular}{lccc}
\hline & \multicolumn{4}{c}{ Caloric content (Kcal/gm dry wt) } \\
Variable & C. carlsbadensis & C. conicaudus & C. longipes \\
\hline Carcass, M & $4.221 \pm 0.202(5)$ & $4.509 \pm 0.222(4)$ & $4.917 \pm 0.067(5)$ \\
Carcass, F & $3.960 \pm 0.041(5)$ & $4.389 \pm 0.126(4)$ & $5.942 \pm 0.069(3)$ \\
Crop contents & $3.982(1)$ & - & - \\
Mixed wastes & $4.042(1)$ & - & - \\
Ova & $5.838(1)$ & - & - \\
Food & $3.977 \pm 0.111(10)$ & - & - \\
\hline
\end{tabular}

Values shown are mean and standard error of the mean: $F=$ female; $M=$ male

Number in parentheses represent the number of samples bombed. 
Table 4. Water budget components

\begin{tabular}{lcccc}
\hline & H. subterraneus & C. stygius & C. carlsbadensis & C. longipes \\
\hline$N$ & 12 & 16 & 16 & 14 \\
Temperature & $13.6 \mathrm{C}$ & $13.6 \mathrm{C}$ & $15.2 \mathrm{C}$ & $15.2 \mathrm{C}$ \\
CELW & 0.408 & 1.180 & 0.284 & 0.120 \\
TBW & 0.300 & 0.836 & 0.1961 & 0.0822 \\
Total loss & 3.164 & 2.220 & 3.560 & 2.527 \\
Wastes loss & 0.927 & 0.896 & 0.528 & 0.140 \\
EWL & 2.283 & 1.351 & 3.032 & 2.387 \\
Food gain & 2.365 & 1.825 & 2.611 & 1.827 \\
Metabolic gain & 0.430 & 0.421 & 0.591 & 0.694 \\
\hline
\end{tabular}

Units for CELW (crop-empty live weight) and TBW (total body water) are in g, while all other values are given in $\mathrm{mg} / \mathrm{g} \mathrm{CELW} / \mathrm{hr}$. Sexes combined in all species. Experiments were done in humid, still air. Data for $H$. subterraneus and $C$. stygius from Studier et al. $(1987 b)$. EWL = evaporative water loss

female-skewed sex ratio observed in most Kentucky caves. No clear pattern of male-female foraging times is seen with the Carlsbad Ceuthophilus, and data on male: female distributions in the caves is limited and requires further study.

Water budget components from $C$. carlsbadensis and $C$. longipes are given in Table 4 with comparable data from the Kentucky crickets (Studier et al., 1987b). The temperature in both studies was the ambient cave temperature in still, humid air. An inverse relationship between mass and weight specific values is expected for all surface-area to mass comparisons. The relationship is consistent in the Kentucky crickets but not with those from Carlsbad, although comparing data from all four species shows the three smaller species tightly clustered compared to the values for evaporative water loss in the large C. stygius. Some differences may be due to attenuation of limbs with increasing cave adaptation and associated effects of surface area.

Cave-adapted organisms are generally expected to have lower metabolic rates than epigean species (Poulson and White, 1969; Culver, 1982); an expectation which is supported by our study. A comparison of metabolic rates (MR in cal/g/hr) in Table 5 shows the expected increase in weight-specific MR with decreasing size (Peters, 1983). All crickets showed MRs which were lower than expected when compared to predictions for epigean species (Kayser and Heusner, 1964).

Cavernicolous crickets and their eggs and guano represent an important and relatively abundant food source for other cave organisms. Their importance in the food chain can be predicted based on knowledge of the biology of the cricket and the caloric value of carcasses, crops, eggs and guano. In terms of weight specific crop calories, Studier et al. (1987) found that the more numerous $H$. subterraneus brings more fixed energy into Kentucky caves per foraging bout than does $C$. stygius. Caloric value of guano from both species was low, and markedly so for $H$. subterraneus, but importance to troglobitic species was offset by much greater numbers of Hadenoecus and its distribution away from entrance areas into deep cave areas. The only Carlsbad species we have comparable data for is $C$. carlsbadensis. The food for this cricket often consists of bat guano, which has a caloric value of $3.977 \pm 0.111 \mathrm{kcal} / \mathrm{g}$ dry wt, essentially identical to the crickets' crop contents value of $3.982 \mathrm{kcal} / \mathrm{g}$ dry wt. This value is similar to crop values for $H$. subterraneus of $3.658 \pm 0.0658$ and $4.012 \pm 0.159 \mathrm{Kcal} / \mathrm{g}$ dry wt for females and males, respectively (Studier et al., 1986) and somewhat less than the $4.47 \pm 1.35 \mathrm{Kcal} / \mathrm{g}$ dry $w \mathrm{t}$ for $C$. stygius females and males (Studier et al., 1987a). The importance of $C$. carlsbadensis as a food resource for troglobites is limited by its occurrence on bat guano and in the highly disturbed area of the Big Room and its rare occurrence deeper into food-poor areas of the cave.

This study of comparative bioenergetics of camel crickets in Carlsbad Caverns National Park has demonstrated that cave-adaptation varies considerably among the three cricket species at Carlsbad and in comparison to the cave and camel crickets from Kentucky studied by Studier et al. (1986, $1987 \mathrm{a}, \mathrm{b})$ in foraging intervals, metabolic rates, and water budgets. Differences among the three Carlsbad

Table 5. Weight-specific metabolic rate, expected and actual metabolic rate (cal/gm/hr) of cave and camel crickets

\begin{tabular}{lccccc}
\hline Species & Sex & $\begin{array}{c}\text { Weight } \\
\text { Specific MR } \\
\text { (cal/g/hr) }\end{array}$ & $\begin{array}{c}\text { Expected } \\
\text { MR } \\
\text { (cal/hr) }\end{array}$ & $\begin{array}{c}\text { Actual } \\
\text { MR } \\
\text { (cal/hr) }\end{array}$ & $\begin{array}{c}\text { Percentage } \\
\text { of } \\
\text { Expected }\end{array}$ \\
\hline C. carlsbadensis & $\mathrm{B}$ & 3.681 & 1.8 & 1.044 & 58 \\
C. longipes & $\mathrm{B}$ & 4.324 & 1.1 & 0.520 & 47.3 \\
C. stygius & $\mathrm{F}$ & $2.612 \pm 0.410$ & 3.29 & $2.61 \pm 0.49$ & 79.3 \\
H. subterraneus & $\mathrm{M}$ & $2.636 \pm 0.477$ & 3.04 & $2.64 \pm 0.48$ & 86.8 \\
\hline
\end{tabular}

Expected rates are based on Kayser and Heusner (1964). Values shown are mean and standard error of the mean: $\mathrm{F}=$ female; $\mathrm{M}=$ male; $\mathrm{B}=$ both. Data for $C$. stgias and $H$. subterraneus from Studier et al. (1986, 1987a). 
species are related to their level of cave adaptation. Further studies of population biology and the effects of temperature and humidity on metabolic rate of the Carlsbad species are indicated.

Act nowledgements - We appreciate assistance in the field by Ke'I Ingham, William "Ziggy" Ziegler, Ann Studier, Steve Serick, Dennis Viele and David Barkley. We thank the Cave Re:earch Foundation for use of their field buildings and

National Park Service personnel at Carlsbad Caverns National Park, especially Ronal Kerbo and David Ek, for pro viding access to the study sites.

\section{REFERENCES}

Bailey V. (1928) Animal life of the Carlsbad Cavern. Monogr. Am. Soc. Mamm. No. 3. Williams and Wilkins Co., Baltimore, MD.

C. mpbell G. D. (1974) Activity rhythm of the cave cricket, Ceuthophilus conicaudus Hubbell. Cave Research Foundation 1974 Annual Report, p. 49.

Cimpbell G. D. (1976) Activity rhythm in the cave cricket, Ceuthophilus conicaudus Hubbell. Am. Midl. Nat. 96, 350-366.

C.tudell A. N. (1916) The genera of the tettiginid insects of the subfamily Rhaphidophorinae found in America north of Mexico. Proc. U.S. Nat. Mus. 49, 655-690.

Cuudell A. N. (1924) Two new species of Ceuthophilus from the Carlsbad Cave in New Mexico (Orthoptera). Proc. Entl. Soc. Wash. 26, 217-221

Culver D. C. (1982) Cave Life; Evolution and Ecology. Vol. IX. Harvard University Press, Cambridge, MA.
Hubbell T. H. (1936) A monographic revision of the genus Ceuthophilus (Orthoptera, Gryllacrididae, Rhaphidophorinae). Univ. Florida Publ. Biol. 2, University of Florida, Gainesville, FL.

Kayser C. and A. Heusner A. (1964) Etude comparative du metabolisme energetique dans la serie animale. J. Physiol., Paris 56, 489-524.

Northup D. E. (1988) Community structure of the arthropods of Carlsbad Cavern emphasizing Rhaphidophoridae of the genus Ceuthophilus. Unpublished Masters Thesis, Department of Biology, University of New Mexico, Alberquerque, NM.

Peters R. H. (1983) The Ecological Implications of Body Size. Cambridge University Press, Cambridge.

Poulson T. L, and White W. B. (1969) The cave environment. Science 165, 971-981.

Studier E. H. and Lavoie K. H. (1990) Biology of cave crickets, Hadenoecus subterraneus, and camel crickets, Ceuthophilus stygius (Insecta:Orthoptera): metabolism and water economies related to size and temperature. Comp. Biochem. Physiol. 95A, 157-161.

Studier E. H. and Lavoie K. H. (1993) Attenuation and annual femur length: mass relationships in cavernicolous crickets (Insecta:Orthoptera). J. Cave and Karst Sci. (Buil. natn. Speleal. Soc.) (in press).

Studier E. H., Lavoie K. H., Wares W. D. II and Linn J. A.-M. (1986) Bioenergetics of the cave cricket, Hadenoecus subterraneus. Comp. Biochem. Physiol. 84A, $431-436$.

Studier E. H., Lavoie K. H., Wares W. D. II and Linn J. A.-M. (1987a) Bioenergetics of the camel cricket, Ceuthophilus stygius. Comp. Biochem. Physiol. 86A, 289-293.

Studier E. H., Wares W. D. II, Lavoie K. H. and Linn J. A.-M. (1987b) Water budgets of cave crickets Hadenoecus subterraneus and camel crickets, Ceuthophilus stygius. Comp. Biochem. Physiol. 86A, 295-300. 